\title{
THE INFORMATION CONTENT OF AUDIT OPINION FOR USERS OF FINANCIAL STATEMENTS
}

\author{
Andreea Claudia Crucean \\ East European Center for Research in Economics and Business, West University of \\ Timisoara, Romania \\ andreea.crucean94@e-uvt.ro
}

\begin{abstract}
In a market economy with frequent changes, audit is an area that can provide some stability at the economic and social lever, even if the economic and financial crises have questioned the audit work and led to a decrease in the trust of the intended users in the auditors work, leading to a distortion of the primary purpose of the financial audit. The article presents the relevant aspects of the evolution of audit reporting, especially on the underlying issues that expressing qualified opinions or disclaimer of opinion. The content of paper includes a review literature, national and international, and a case study that identified and analyzed the qualified opinions expressed in the auditor's independent reports, after analysis the financial statements of companies listed on the Bucharest Stock Exchange for the period 2015, 2016 and 2017. The entities were grouped on 9 sectors of activity and researched for each industry if the auditors expressed an unqualified opinion or a modified opinion and if the auditor is part of a Big 4 company or belongs to another auditor category. The reasons behind the modified opinions were analyzed and grouped according to the frequency of their appearance in the audit reports. The most important conclusion of the case study was that in all cases, the reasons that led to express modified opinions, was detailed in the auditor's report, this being considered as a reference guide for the future auditor's missions, as well as, a recommendation for improving the highlighted aspects.
\end{abstract}

Keywords: auditor's report, modified opinion, disclaimer of opinion, financial statements, financial reporting, Big4.

JEL classification: M40, M42.

\section{Introduction}

The activity that the financial auditor carries out does not provide an absolute guarantee, but he is responsible for the opinion expressed on the basis of the evidence collected to properly inform users about the financial statements.

Auditor's report does not bring added value if the public does not trust the information offered by the auditor, or if it is considered that it could offer more than that (Mock, 2013).

Through this paper aims to emphasize the importance of issuing an appropriate opinion, which reflects that the financial statements were elaborated in accordance with the applicable financial reporting framework, but also the mention in the auditor's report of the reasons that lead to express another opinion that one unqualified. In the case study were analyzed 62 companies listed on the Bucharest Stock Exchange (BSE). Entities were grouped by industry, depending on the object of activity and it is done an analysis of the information from the financial statements and auditor's report. As a result of systematization of the data were identified qualified opinions and disclaimer of opinion and were explained the reasons that led to express this. 


\section{Theoretical considerations}

Currently, the global economy is constantly changing, being influenced by the changes made at the social, political and legislative level. An instrument created by the needs of participants in the economy to provide assurance on the quality and reliability of the information provided by the entity's financial statements is the audit. As a result of the auditor's work, based on the audit evidence collected, he formulates an opinion on the information analyzed, being expressed in the Independent Auditor's Report (Mortura, 2018) Kiss, Fulop and Cordoș (2015) believe that the interest for the form and content of the audit report is higher than ever, and it represents a reaction to the financial crisis and financial scandals of recent years. Investors are cautious because of accounting frauds, so their requirement for a revised audit report and a quality audit is considered justified.

Regulators (International Auditing and Assurance Standards Board) and researchers have focused their attention on this issue, and the reforms are to appear quickly as the revised standards have been published at the beginning of 2015 and will come into effect from 2016. With these revisions, the degree of transparency of information has also been amended, thereby increasing the degree of assurance on compliance with the code of corporate governance of the entity.

In addressing international regulations, the audit report has a triple role (Horomnea, 2010):

- Instrument for communication with users of the financial statements prepared by the entity, mainly with shareholders and the public, for substantiating economic decisions;

- A tool for confirming the confidence of shareholders and the public in the financial statements presented by the entity;

- Identification tool of responsibilities for auditor and for the management of the audited entity.

Botez (2015) considers that the paragraph about opinion expresses in a synthesized form the auditor's conclusion about the financial statements and the belief that the auditor expresses an opinion on the compliance of the accounting references with the International Financial Reporting Standards.

Kiss, Fulop and Cordos (2015) show that the auditor's opinion is very important, it is considered that the statutory audit report should provide more transparency as to what actions the statutory auditor carries out on an audit mission and how it reaches the results of his work.

The new regulations issued in January 2015 of the International Auditing and Assurance Standards Board (IAASB) has emerged in this context. These are intended to develop the audit report in order to provide more information on what the auditor considers most relevant in the audit. These IAASB regulations are an important first step to address the needs of users who want to get a more comprehensive picture of the performed audit

According to Mortura (2017) the form of the new Independent Auditor's Report is more complex, generating greater transparency in the information provided by the auditor. The purpose of changing the structure and content of the report is to increase the confidence of users of financial statements in the auditor's work and to more clearly present the auditor's responsibilities in an audit of the financial statements.

The auditor's opinion may be influenced by the quality on audit, supported by the competence requirements, the ethical and professional conduct that the auditor should consider when fills is the mandate received. Competence is needed throughout the mission and leads to opinion based on the evidence, guaranteed by the auditor's independence and objectivity (Robu et al., 2016).

Hategan and Crucean (2018) speak about the companies listed on the BSE from the perspective of subsequent events that occurring before or after the date of the audit report, events that in some cases may influence the auditor's opinion or may cause the auditor to issue a different audit opinion than the first issued, taking into account the impact that these subsequent events can change the annual financial statements. 
Barnes, Cussatt and Harp (2018) consider that the smaller auditors (non-Big4) were being stimulated to provide quality audits to attract and retain customers (national reputation) whit larger auditors (Big4) have more to lose from reputational damage.

Chen and Hassan (2018) argue that the companies with collaboration culture can enhance the quality of information available within the organization; this high-quality internal information environment is examined and analyzed by auditors, leading to decreased audit risk and audit fees.

Francis, Wu and Siraj (2017) have found that auditor's experience of auditing firms from different industries was significantly and positively associated with audit fees. Also, the authors find that auditors who have extensive experience in several areas also change higher audit fees for the diversified firms.

Fulop (2018) considers that always when an opinion is different from the one unmodified, the auditor should add an explanatory paragraph in the auditor's report, explaining the reasons for his opinion.

\section{Methodology}

In research were studied 62 companies listed on Bucharest Stock Exchange (BSE), with non-financial activity. Based on the annual reports published for the period $2015-2017$ the companies were grouped on 9 sectors of activity. After analyzing the annual reports and the audit reports for the mentioned period, were synthesized how many entities submitted unqualified opinions and how many presented modified opinions. Also were structured the opinions that was found and grouped them by auditor categories, justifying the reasons that led to express modified opinions, according to the frequency that its meet in the audit reports.

\section{Results}

\subsection{Statistics of audit opinions issued in the period $2015-2017$}

To synthesize the results of the analysis, I explained in the following table, for each year of analysis, the status of the audit opinions expressed, and their breakdown into two categories of auditors: Big 4 PricewaterhouseCoopers (Pwc), KMPG, Deloitte Touche Tohmatsu, Ernst Young (E\&Y) and other audit entities.

Table 1: Opinions issued during the analysis period

\begin{tabular}{|c|c|c|c|c|c|c|}
\hline Year & $\begin{array}{c}\text { Total } \\
\text { number of } \\
\text { companies }\end{array}$ & \multicolumn{2}{|c|}{ Opinion } & \multicolumn{2}{c|}{ Auditor } & Modified opinions \\
were express by?
\end{tabular}

Source: author's own projection

Differences from one year to the next are not so significant, in the first year of analysis (2015) from the total of 64 audited companies, were issued 52 unqualified opinions and 12 modified 
opinions. After a detailed analysis, from the total of 12 modified opinions (8 in the manufacturing industry and 3 in the supply, accommodation, construction and financial industry), only 7 were issued by a Big 4 company, the difference of 5 being issued by other auditors.

The second year of analysis, 2016, shows an almost similar situation, from the total of 64 audited companies, were issued 53 unqualified opinions and 11 modified opinions. After a detailed analysis, from the total of 11 modified opinions ( 8 in the manufacturing industry and 3 in the supply, accommodation and financial industry), only 3 were issued by a Big 4 company, the difference of 8 being issued by other auditors.

An almost similar situation has encountered in the last year of analysis, 2017,_where from the total of 64 audited entities were issued 52 unqualified opinions and 12 modified opinions ( 9 in the manufacturing industry and 3 opinions in the supply, accommodation and financial industry). Similar to the previous year, 3 modified opinions were issued by a Big 4 company and the difference of 9 modified opinions by other auditors.

The table no. 3 contains a more in-depth approach of the modified opinions, as well as, of the auditor category that was grouped into two categories: Big4 and NonBig4. From the total of 62 companies analyzed, only 12 presented modified opinions (qualified and disclaimer).

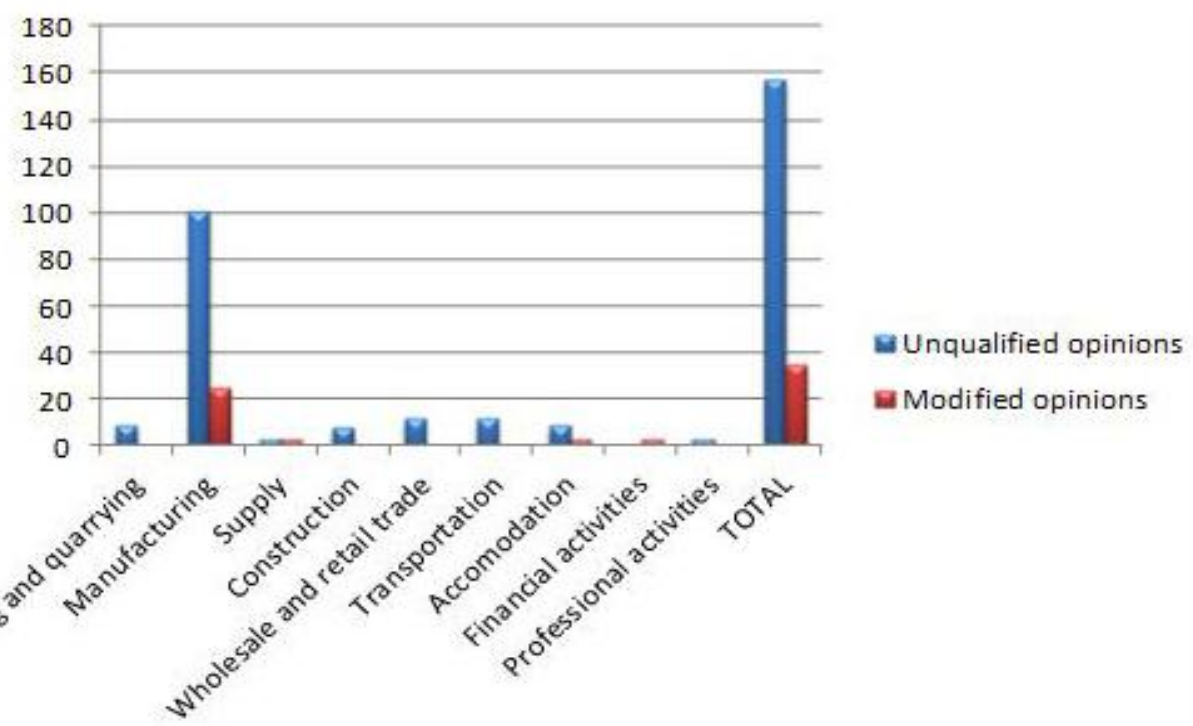

Figure 1: Audit opinions expressed from the financial statements on the period 2015-2017 Source: author's own projection

In the Figure 1 are presented the audit opinions expressed after the analysis of the financial statements for each industry. It can be seen that the most significant share is held by the manufacturing industry. This is due to the fact that this industry has more entities than the other industries analyzed. Unqualified opinions are collared in blue, and at the opposite, the modified opinions in red. The second category is not significant because the balance of the modified opinions in the total opinions is much lower than the balance of the unqualified opinions in the same total.

\subsection{The reasons for the modified opinions}

In the Table 2 are presented the reasons that were behind the issuance of the modified opinions by the auditors. The reasons were analyzed for each entity, starting from the review of the audit reports issued during the analysis period. 
Table 2: The frequency of reasons for the qualified opinions

\begin{tabular}{|c|c|c|c|c|}
\hline Reason & Entity & Year & Explication & Industry \\
\hline \multirow[t]{5}{*}{$\begin{array}{l}\text { Uncertainties } \\
\text { about going } \\
\text { concern }\end{array}$} & Armătura S.A. & $\begin{array}{l}2015 \\
2016 \\
2017\end{array}$ & $\begin{array}{l}\text { Recording net loss and } \\
\text { significant cumulative loss }\end{array}$ & Manufacturing \\
\hline & $\begin{array}{l}\text { Electroputere } \\
\text { S.A. }\end{array}$ & $\begin{array}{l}2016 \\
2017 \\
\end{array}$ & $\begin{array}{l}\text { Recording net loss and } \\
\text { significant cumulative loss }\end{array}$ & Manufacturing \\
\hline & $\begin{array}{l}\text { Nuclear } \\
\text { Electrica S.A. }\end{array}$ & $\begin{array}{l}2016 \\
2017 \\
\end{array}$ & $\begin{array}{l}\text { Uncertainties about going } \\
\text { concern of a branch }\end{array}$ & Supply \\
\hline & Otlchim S.A. & 2016 & $\begin{array}{l}\text { Open insolvency } \\
\text { proceedings }\end{array}$ & Manufacturing \\
\hline & Romcab S.A. & 2017 & $\begin{array}{l}\text { Open insolvency } \\
\text { proceedings }\end{array}$ & Manufacturing \\
\hline \multirow[t]{5}{*}{$\begin{array}{l}\text { Non compliance } \\
\text { IAS }\end{array}$} & Natura Q S.A. & $\begin{array}{l}2015 \\
2016\end{array}$ & IAS 39 & Financial \\
\hline & Retrasib S.A. & $\begin{array}{l}2016 \\
2017\end{array}$ & IAS 11 and IAS 29 & Manufacturing \\
\hline & $\begin{array}{l}\text { Electroputere } \\
\text { S.A. }\end{array}$ & 2016 & IAS 11 & Manufacturing \\
\hline & Oltchim S.A. & 2017 & IAS 8 & Manufacturing \\
\hline & Turism S.A. & 2017 & IAS 37 & Accommodation \\
\hline \multirow[t]{5}{*}{ Uncertain claims } & Natura Q S.A. & $\begin{array}{l}2015 \\
2016 \\
2017 \\
\end{array}$ & $\begin{array}{l}\text { Claims with overdue } \\
\text { maturity and uncertain } \\
\text { recovery }\end{array}$ & Financial \\
\hline & Turism S.A. & 2016 & Claims uncollectible. & Accommodation \\
\hline & Romcab S.A. & $\begin{array}{l}2015 \\
2016 \\
2017\end{array}$ & $\begin{array}{l}\text { Claims with suppliers in } \\
\text { insolvency }\end{array}$ & Manufacturing \\
\hline & $\begin{array}{l}\text { Electroputere } \\
\text { S.A. }\end{array}$ & $\begin{array}{l}2015 \\
2016 \\
\end{array}$ & $\begin{array}{l}\text { Commercial claims } \\
\text { recorded erroneously. }\end{array}$ & Manufacturing \\
\hline & Retrasib S.A. & $\begin{array}{l}2015 \\
2016 \\
2017\end{array}$ & $\begin{array}{l}\text { Claims relating to on } \\
\text { deferred tax due for the tax } \\
\text { loss }\end{array}$ & Manufacturing \\
\hline \multirow[t]{2}{*}{$\begin{array}{l}\text { Transactions } \\
\text { with affiliated } \\
\text { parties }\end{array}$} & Natura Q S.A. & $\begin{array}{l}2016 \\
2017\end{array}$ & $\begin{array}{l}\text { Transactions with affiliated } \\
\text { parties without transfer } \\
\text { pricing file }\end{array}$ & Financial \\
\hline & Ves S.A. & 2017 & $\begin{array}{l}\text { Transactions with affiliated } \\
\text { parties without transfer } \\
\text { pricing file }\end{array}$ & Manufacturing \\
\hline \multirow{2}{*}{$\begin{array}{l}\text { Internal control } \\
\text { deficiencies }\end{array}$} & Retrasib S.A. & 2016 & Incorrectly performed tests & Manufacturing \\
\hline & Ves S.A. & $\begin{array}{l}2016 \\
2017\end{array}$ & SAP software & Manufacturing \\
\hline $\begin{array}{l}\text { Debts not } \\
\text { reimbursed }\end{array}$ & Armătura S.A. & $\begin{array}{l}2016 \\
2017\end{array}$ & $\begin{array}{l}\text { Non-repayable loan, } \\
\text { the entity does not have } \\
\text { cash for restitution, action } \\
\text { that led to litigation }\end{array}$ & Manufacturing \\
\hline $\begin{array}{l}\text { Non compliance } \\
\text { contracts }\end{array}$ & $\begin{array}{l}\text { Electroputere } \\
\text { S.A. }\end{array}$ & $\begin{array}{l}2015 \\
2016\end{array}$ & $\begin{array}{l}\text { Non-fulfilment the } \\
\text { obligations stipulated in } \\
\text { the employment contracts }\end{array}$ & Manufacturing \\
\hline
\end{tabular}




\begin{tabular}{|c|c|c|c|c|}
\hline Reason & Entity & Year & Explication & Industry \\
\hline \multirow[t]{5}{*}{$\begin{array}{l}\text { Fluctuations of } \\
\text { assets }\end{array}$} & Armătura S.A. & $\begin{array}{l}2016 \\
2017\end{array}$ & $\begin{array}{l}\text { The net asset value } \\
\text { dropped below the } \\
\text { subscribed share capital }\end{array}$ & Manufacturing \\
\hline & $\begin{array}{l}\text { Mecanica } \\
\text { Ceahlău S.A. }\end{array}$ & 2016 & $\begin{array}{l}\text { Recording tangible assets } \\
\text { (overstatement of current } \\
\text { result and sub-valuation of } \\
\text { result report) }\end{array}$ & Manufacturing \\
\hline & $\begin{array}{l}\text { Mecanica } \\
\text { Fină S.A. }\end{array}$ & $\begin{array}{l}2015 \\
2016 \\
2017 \\
\end{array}$ & $\begin{array}{l}\text { Tangible assets for which } \\
\text { cannot be estimated net } \\
\text { realizable value }\end{array}$ & Manufacturing \\
\hline & $\begin{array}{l}\text { Nuclear } \\
\text { Electrica S.A. }\end{array}$ & 2016 & $\begin{array}{l}\text { Tangible assets } \\
\text { capitalized for a branch in } \\
\text { insolvency }\end{array}$ & Supply \\
\hline & $\begin{array}{l}\text { Electroputere } \\
\text { S.A. }\end{array}$ & $\begin{array}{l}2016 \\
2017 \\
\end{array}$ & $\begin{array}{l}\text { Tangible assets that } \\
\text { requiring adjustment }\end{array}$ & Manufacturing \\
\hline \multirow[t]{3}{*}{$\begin{array}{l}\text { Evaluations and } \\
\text { revaluations }\end{array}$} & Oltchim S.A. & $\begin{array}{l}2015 \\
2016 \\
\end{array}$ & $\begin{array}{l}\text { Not doing the evaluation } \\
\text { for insolvency proceedings }\end{array}$ & Manufacturing \\
\hline & Ves S.A. & $\begin{array}{l}2016 \\
2017\end{array}$ & $\begin{array}{l}\text { Not doing the revaluation } \\
\text { of buildings and lands }\end{array}$ & Manufacturing \\
\hline & $\begin{array}{l}\text { Mecanica } \\
\text { Fină S.A. }\end{array}$ & 2017 & $\begin{array}{l}\text { Positive and negative } \\
\text { revaluation differences }\end{array}$ & Manufacturing \\
\hline \multirow[t]{3}{*}{$\begin{array}{l}\text { Non-participation } \\
\text { to inventory }\end{array}$} & Retrasib S.A. & 2016 & $\begin{array}{l}\text { Auditing process was } \\
\text { established after that the } \\
\text { companies had the } \\
\text { inventory; in which case } \\
\text { the auditor could not take } \\
\text { part to inventory }\end{array}$ & Manufacturing \\
\hline & Sinteza S.A. & 2017 & $\begin{array}{l}\text { Auditing process was } \\
\text { established after that the } \\
\text { companies had the } \\
\text { inventory; in which case } \\
\text { the auditor could not take } \\
\text { part to inventory }\end{array}$ & Manufacturing \\
\hline & Ves S.A. & 2017 & $\begin{array}{l}\text { Auditing process was } \\
\text { established after that the } \\
\text { companies had the } \\
\text { inventory; in which case } \\
\text { the auditor could not take } \\
\text { part to inventory }\end{array}$ & Manufacturing \\
\hline \multirow[t]{3}{*}{$\begin{array}{l}\text { Costs } \\
\text { capitalization }\end{array}$} & Romcab S.A. & $\begin{array}{l}2016 \\
2017\end{array}$ & Prepayments capitalized & Manufacturing \\
\hline & $\begin{array}{l}\text { Mecanica } \\
\text { Ceahlău S.A. }\end{array}$ & $\begin{array}{l}2016 \\
2017\end{array}$ & $\begin{array}{l}\text { Capitalizing costs of } R \& D \\
\text { projects as well as ongoing } \\
\text { assets }\end{array}$ & Manufacturing \\
\hline & $\begin{array}{l}\text { Nuclear } \\
\text { Electrica S.A. }\end{array}$ & $\begin{array}{l}2015 \\
2017\end{array}$ & $\begin{array}{l}\text { Tangible assets which } \\
\text { were capitalized } \\
\text { incorrectly }\end{array}$ & Supply \\
\hline Inconsistencies & Ves S.A. & 2016 & Initial balances that could & Manufacturing \\
\hline
\end{tabular}




\begin{tabular}{|l|l|l|l|l|}
\hline \multicolumn{1}{|c|}{ Reason } & Entity & Year & \multicolumn{1}{c|}{ Explication } & Industry \\
\hline $\begin{array}{l}\text { between the } \\
\text { initial balances } \\
\text { and the final } \\
\text { balances }\end{array}$ & & 2017 & not be confirmed & \\
\hline $\begin{array}{l}\text { Provisions and } \\
\text { adjustments }\end{array}$ & Armătura S.A. & 2017 & $\begin{array}{l}\text { There were no provisions } \\
\text { for litigation and benefits } \\
\text { for employees at } \\
\text { retirement age }\end{array}$ & Manufacturing \\
\cline { 2 - 6 } & $\begin{array}{l}\text { Mecanica } \\
\text { Ceahlău S.A. }\end{array}$ & 2017 & $\begin{array}{l}\text { Lands that require } \\
\text { adjustment }\end{array}$ & Manufacturing \\
\cline { 2 - 6 } & Turism S.A. & 2017 & $\begin{array}{l}\text { Depreciations of the } \\
\text { participation titles }\end{array}$ & Accommodation \\
\cline { 2 - 6 } & Natura Q S.A. & 2017 & $\begin{array}{l}\text { Adjustments uncertain } \\
\text { claims }\end{array}$ & Financial \\
\hline $\begin{array}{l}\text { Returns and } \\
\text { commissions }\end{array}$ & $\begin{array}{l}\text { Mecanica } \\
\text { Ceahlău S.A. }\end{array}$ & 2017 & $\begin{array}{l}\text { Returns and commissions } \\
\text { with current value greater } \\
\text { than the estimated value }\end{array}$ & Manufacturing \\
\hline
\end{tabular}

Source: author's own projection

The main reasons that the auditors encountered when they expressed qualified opinions, were related to uncertainties about going concern, most companies presenting reasons that support these uncertainties. The same frequency was for the non compliance IAS or the first use of these standards, but also uncertain claims or overdue maturity and fluctuations of assets, especially of immobilizations. Also was met, repeatedly, the omitting to record provisions or adjustments for assets that need this forecast, reason present in three analyzed industries. At a lower frequency was met the companies that registered transactions with affiliated parties, but had not completed the transfer pricing file. Another aspect behind the issue modified opinions was that the start of auditing process was established after that the companies had the inventory, in which case the auditor could not take part to inventory. Do not record revaluation differences or not evaluating land and buildings at the right time, as well as, the capitalization of costs, were reasons found with the same frequency in the auditor's reports. Another reason for the ranking is represented by deficiencies encountered in the internal control system or in the accounting software and mistaken tests. This reason was only met in the manufacturing and financial industries. The last place was occupied by reasons found only in the manufacturing industry, related to: returns and commissions with current value greater than the estimated value, failure the obligations to the employees stipulated in the employment contracts, loans not repaid at the right time and initial balances that could not be confirmed or inconsistent between the initial balances and the final balances.

Table no. 2 contains the modified opinions, as well as the auditor's category grouped into two categories: Big4 and NonBig4. Of the total of 62 companies analyzed, only 12 companies listed were in case to express modified opinions.

The reasons have been grouped in the Figure 3, by the frequency that I have encountered in the audit reports, from the largest to the smallest. 


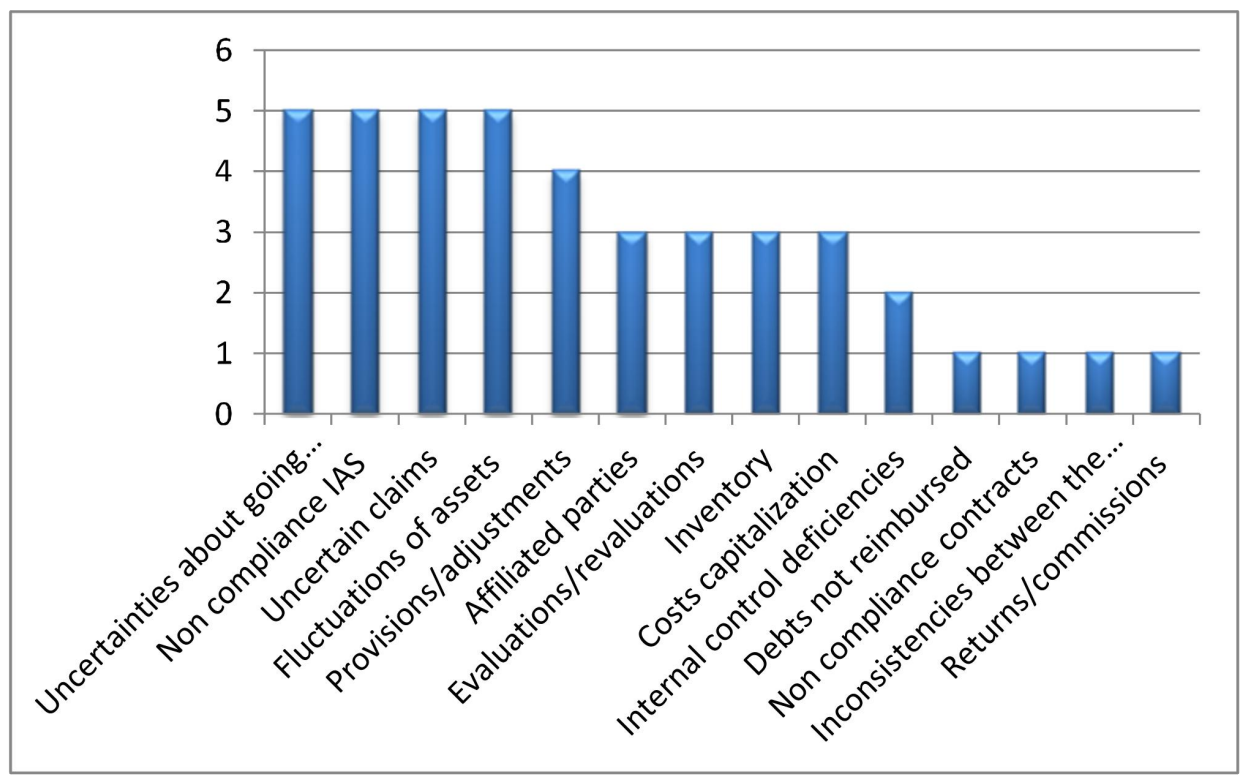

Figure 2: The reasons for the qualified opinions

Source: author's own projection

In Table 3 was presented the comparison of auditor's opinions for companies with modified opinions. From all companies, some entities showed particular situations. One company changed the auditor's category, so the audit opinion was differed in the studied period.

Table 3: Auditor's opinion

\begin{tabular}{|c|c|c|c|c|c|c|}
\hline \multirow[t]{2}{*}{ Company - Industry } & \multicolumn{2}{|c|}{ Year 2017} & \multicolumn{2}{|c|}{ Year 2016} & \multicolumn{2}{|c|}{ Year 2015} \\
\hline & Auditor & Opinion & Auditor & Opinion & Auditor & Opinion \\
\hline $\begin{array}{l}\text { ARMATURA S.A. - } \\
\text { Manufacturing }\end{array}$ & Non Big4 & $\begin{array}{l}\text { Disclaimer } \\
\text { of opinion }\end{array}$ & $\begin{array}{l}\text { Non } \\
\text { Big4 }\end{array}$ & $\begin{array}{l}\text { Disclaimer } \\
\text { of opinion }\end{array}$ & $\begin{array}{l}\text { Non } \\
\text { Big4 }\end{array}$ & $\begin{array}{l}\text { Disclaimer } \\
\text { of opinion }\end{array}$ \\
\hline $\begin{array}{l}\text { ELECTROPUTERE } \\
\text { S.A. - Manufacturing }\end{array}$ & Big4 & $\begin{array}{l}\text { Qualified } \\
\text { opinion }\end{array}$ & Big4 & $\begin{array}{l}\text { Qualified } \\
\text { opinion }\end{array}$ & Big 4 & $\begin{array}{l}\text { Qualified } \\
\text { opinion }\end{array}$ \\
\hline $\begin{array}{l}\text { IMPACT DEVELOPER } \\
\text { \& CONTRACTOR } \\
\text { S.A. - Construction }\end{array}$ & Big 4 & $\begin{array}{l}\text { Unqualified } \\
\text { opinion }\end{array}$ & Big 4 & $\begin{array}{l}\text { Unqualified } \\
\text { opinion }\end{array}$ & Big 4 & $\begin{array}{l}\text { Qualified } \\
\text { opinion }\end{array}$ \\
\hline $\begin{array}{l}\text { MECANICA } \\
\text { CEAHLAU - } \\
\text { Manufacturing }\end{array}$ & Big4 & $\begin{array}{l}\text { Qualified } \\
\text { opinion }\end{array}$ & Big4 & $\begin{array}{l}\text { Qualified } \\
\text { opinion }\end{array}$ & Big 4 & $\begin{array}{l}\text { Unqualified } \\
\text { opinion }\end{array}$ \\
\hline $\begin{array}{l}\text { MECANICA FINA SA - } \\
\text { Manufacturing }\end{array}$ & Non Big4 & $\begin{array}{l}\text { Qualified } \\
\text { opinion }\end{array}$ & $\begin{array}{l}\text { Non } \\
\text { Big4 }\end{array}$ & $\begin{array}{l}\text { Qualified } \\
\text { opinion }\end{array}$ & $\begin{array}{l}\text { Non-Big } \\
4\end{array}$ & $\begin{array}{l}\text { Qualified } \\
\text { opinion }\end{array}$ \\
\hline $\begin{array}{l}\text { OLTCHIM S.A. RM. } \\
\text { VALCEA - } \\
\text { Manufacturing }\end{array}$ & Big4 & $\begin{array}{l}\text { Qualified } \\
\text { opinion }\end{array}$ & $\begin{array}{l}\text { Non } \\
\text { Big4 }\end{array}$ & $\begin{array}{l}\text { Qualified } \\
\text { opinion }\end{array}$ & Big 4 & $\begin{array}{l}\text { Qualified } \\
\text { opinion }\end{array}$ \\
\hline $\begin{array}{l}\text { PRODPLAST S.A. - } \\
\text { Manufacturing }\end{array}$ & Big 4 & $\begin{array}{l}\text { Unqualified } \\
\text { opinion }\end{array}$ & Big 4 & $\begin{array}{l}\text { Unqualified } \\
\text { opinion }\end{array}$ & Big 4 & $\begin{array}{l}\text { Qualified } \\
\text { opinion }\end{array}$ \\
\hline $\begin{array}{l}\text { RETRASIB SA - } \\
\text { Manufacturing }\end{array}$ & Non Big4 & $\begin{array}{l}\text { Qualified } \\
\text { opinion }\end{array}$ & Big4 & $\begin{array}{l}\text { Disclaimer } \\
\text { of opinion }\end{array}$ & Big 4 & $\begin{array}{l}\text { Unqualified } \\
\text { opinion }\end{array}$ \\
\hline $\begin{array}{l}\text { ROMCAB SA - } \\
\text { Manufacturing }\end{array}$ & Non Big4 & $\begin{array}{l}\text { Qualified } \\
\text { opinion }\end{array}$ & $\begin{array}{l}\text { Non } \\
\text { Big4 }\end{array}$ & $\begin{array}{l}\text { Qualified } \\
\text { opinion }\end{array}$ & $\begin{array}{l}\text { Non-Big } \\
4\end{array}$ & $\begin{array}{l}\text { Qualified } \\
\text { opinion }\end{array}$ \\
\hline $\begin{array}{l}\text { SINTEZA S.A. - } \\
\text { Manufacturing }\end{array}$ & Non Big4 & $\begin{array}{l}\text { Qualified } \\
\text { opinion }\end{array}$ & $\begin{array}{l}\text { Non } \\
\text { Big4 }\end{array}$ & $\begin{array}{l}\text { Unqualified } \\
\text { opinion }\end{array}$ & $\begin{array}{l}\text { Non-Big } \\
4\end{array}$ & $\begin{array}{l}\text { Qualified } \\
\text { opinion }\end{array}$ \\
\hline
\end{tabular}




\begin{tabular}{|c|c|c|c|c|c|c|}
\hline \multirow[t]{2}{*}{ Company - Industry } & \multicolumn{2}{|c|}{ Year 2017} & \multicolumn{2}{|c|}{ Year 2016} & \multicolumn{2}{|c|}{ Year 2015} \\
\hline & Auditor & Opinion & Auditor & Opinion & Auditor & Opinion \\
\hline $\begin{array}{lrl}\text { VES } & \text { SA } & - \\
\text { Manufacturing }\end{array}$ & Non Big4 & $\begin{array}{l}\text { Qualified } \\
\text { opinion }\end{array}$ & $\begin{array}{l}\text { Non } \\
\text { Big4 }\end{array}$ & $\begin{array}{l}\text { Qualified } \\
\text { opinion }\end{array}$ & $\begin{array}{l}\text { Non-Big } \\
4\end{array}$ & $\begin{array}{l}\text { Unqualified } \\
\text { opinion }\end{array}$ \\
\hline $\begin{array}{l}\text { S.N. } \\
\text { NUCLEARELECTRICA } \\
\text { S.A. - Electricity, gas, } \\
\text { steam and air supply }\end{array}$ & Non Big4 & $\begin{array}{l}\text { Qualified } \\
\text { opinion }\end{array}$ & $\begin{array}{l}\text { Non } \\
\text { Big4 }\end{array}$ & $\begin{array}{l}\text { Qualified } \\
\text { opinion }\end{array}$ & $\begin{array}{l}\text { Non-Big } \\
4\end{array}$ & $\begin{array}{l}\text { Qualified } \\
\text { opinion }\end{array}$ \\
\hline $\begin{array}{l}\text { TURBOMECANICA } \\
\text { S.A. - Manufacturing }\end{array}$ & Big 4 & $\begin{array}{l}\text { Unqualified } \\
\text { opinion }\end{array}$ & Big 4 & $\begin{array}{l}\text { Unqualified } \\
\text { opinion }\end{array}$ & Big 4 & $\begin{array}{l}\text { Qualified } \\
\text { opinion }\end{array}$ \\
\hline $\begin{array}{l}\text { TURISM, HOTELURI, } \\
\text { RESTAURANTE } \\
\text { MAREA NEAGRA S.A. } \\
\text { - Accommodation and } \\
\text { food service activities }\end{array}$ & Non Big4 & $\begin{array}{l}\text { Qualified } \\
\text { opinion }\end{array}$ & $\begin{array}{l}\text { Non } \\
\text { Big4 }\end{array}$ & $\begin{array}{l}\text { Qualified } \\
\text { opinion }\end{array}$ & $\begin{array}{l}\text { Non-Big } \\
4\end{array}$ & $\begin{array}{l}\text { Qualified } \\
\text { opinion }\end{array}$ \\
\hline $\begin{array}{l}\text { NATURA QUATTUOR } \\
-\quad \text { ENERGIA } \\
\text { HOLDINGS - Financial } \\
\text { and insurance activities }\end{array}$ & Non Big4 & $\begin{array}{l}\text { Qualified } \\
\text { opinion }\end{array}$ & $\begin{array}{l}\text { Non } \\
\text { Big4 }\end{array}$ & $\begin{array}{l}\text { Qualified } \\
\text { opinion }\end{array}$ & $\begin{array}{l}\text { Non-Big } \\
4\end{array}$ & $\begin{array}{l}\text { Qualified } \\
\text { opinion }\end{array}$ \\
\hline
\end{tabular}

Source: author's own projection

The company Retrasib S.A. shows a particular situation, the auditor being changed from a Big 4 company who in 2015 was issued a modified opinion, in 2016 was unable to express an audit opinion into a non-Big4 company that in 2017 issued a qualified opinion. The auditor issued a disclaimer of opinion because the entity has recorded significant cumulative losses, reason that leads to uncertainties about going concern. Other reasons that have influenced the auditor's opinion are about the revaluation differences, the non compliance IAS, and the auditing process that was established after that the companies had the inventory.

The entity Oltchim S.A. was audited in 2015 and in 2017 by a Big 4 company and in 2016 although the auditor was changed to a non-Big 4 company, the opinion remained unchanged.

A more special situation is presented by the entity Sinteza S.A. which has passed from a qualified opinion in 2015, to an unqualified opinion in 2016 and in 2017 return to unqualified opinion, all three opinions being expressed by a non-Big4 company.

In the situation in which the auditor was changed but the audit opinion has been modified, are also the entities: Ves S.A. (NonBig4), Turbomecanica S.A. (Big4), Prodplast S.A. (Big 4), Mecanica Ceahlau S.A. (Big4), Impact developer \& contractor S.A. (Big4).

Within the other entities, even if the auditor's category evolved, the audit opinion issued was remained unchanged.

\section{Conclusions}

Throughout this article presented the theoretical and practical aspects regarding to the audit reporting and the issuing the auditor's opinion. The topic about the auditor's opinion about the financial statements remains an important subject to be followed by auditors, by the entity's management and by the users of the financial statements, when they take investment or strategic decisions.

The opinion that an auditor express after the analysis of the annual financial statements facilitates the confidence in these reports for the both parties, the audit board and the users of the entity results. The audit reporting is a complex activity and the opinion expressed by the auditor has an important contribution to investors' decisions because they are prudent to financial-accounting frauds, so their requirement for a revised audit report and a quality audit is warranted. The case study was focused on non-financial entities listed on the BSE to found if the auditors expressed modified opinions and if it were justifiable. A sample of 62 
companies was fixed and after that was analyzed the annual reports and the audit reports of each company for the period 2015-2017. The auditors were divided into two categories, as well as the auditor's opinion for each year and the reasons behind the issuance of the modified opinions.

In conclusion many entities were audited by a Big4 auditor, this trend being in a continuous increase from year to year, and the most repetitive reasons behind the expressed modified opinions were related to: uncertainties about going concern, non-compliance with IAS standards, uncertain claims or the fluctuations of assets.

The limits of the research were the fact that is not a certified database; the data was collected manually, being retrieved from information published by the companies, their confidence being provided by the independent auditor's reports.

Future research directions can be materialized into expanding the number of companies and the period of study, as well as, a comparative analysis of the audit reports that present qualified opinions, of the companies from different countries.

Acknowledgements: The article is based on a contribution presented at $9^{\text {th }}$ International Conference of Doctoral Students and Young Researchers "Emerging Markets Economics and Business", 21 November 2018, Oradea - Romania, and represents an extended version of it.

\section{References}

Barnes, B.G., Cussatt, M., Harp, N., 2018. Audit Firm Reputation and Perceived Audit Quality: Evidence from Envelopegate, Available: https://ssrn.com/abstract=3240290, [accessed at 04 Nov 2018].

Botez, D., 2015. Aspects Regarding the Quality of Statutory Audit Reports, Audit Financiar Journal, 3 (123), pp. 82-89.

Bucharest Stock Exchange, Annual financial statements of companies for the period 2015 -2017, available at www.bvb.ro [accessed at 03 Nov 2018].

Chen, H., Hassan, T., 2018. How do Auditors View Corporate Culture? The effect of collaboration on Auditure Fees, Available:

http://fmaconferences.org/SanDiego/Papers/culture auditing FMA.pdf [accessed at 04 Nov 2018].

Francis, B., Qiang, W., Siraj, I., 2017. Auditor's Diversified Experience and Audit Characteristics,Available:http://www.fmaconferences.org/Boston/Auditors diversified expe rience and audit characteristics.pdf [accessed at 03 Nov 2018].

Fulop M. T., 2018. New tendencies in audit reporting, examples of good practices BVB, Audit Financiar Journal, 2 (150), pp. 249-260.

Hategan, C.D., Crucean, A.C., 2018. Reporting of subsequent events in financial statements- between obligation and necessity, Audit Financiar Journal, 4 (152), pp. 571 583.

Horomnea, E., 2010. Financial Audit. Concepts. Standards. Rules, Alfa Publishing House, lasi.

Kiss, C., Fulop, M.T., Cordoș, G.S., 2015. Relevant Aspects of Changes to the Statutory Audit Report in the Light of International Regulations, Audit Financiar Journal, 6 (126), pp. 63-73.

Mock, T.J., Bedard, J., Coram, P.J., Davis, S.M., Espahbodi, R., Warne R.C., 2013. The audit reporting model: current research synthesis and implications, Auditing: A Journal of Practice and Theory, 32 (1), pp. 323-351. 
Mortura, L.A., 2017. Analysis of the Amendments to the Independent Auditor's Report Starting with the Auditing of the Financial Statements as at 31.12.2016, "Ovidius" University Annals, Economic Sciences Series, XVII (2), pp. 588-592, Available: http://stec.univ-ovidius.ro/html/anale/ENG/ovidius-university-annals-economic-sciences-se ries-volume-xvii-issue-2/, [accessed at 05 Jan 2019].

Mortura, L.A., 2018. Amendments to the Audit Report for the Review of International Standards on Auditing, ,"Ovidius" University Annals, Economic Sciences Series, XVII (1), pp. 539-544, Available: http://stec.univ-ovidius.ro/html/anale/ENG/ovidius-university-annals-economic-sciences-se ries-volume-xvii-issue-1/, [accessed at 05 Jan 2019].

Mortura, L.A., 2017. Analysis of the Amendments to the Independent Auditor's Report Starting with the Auditing of the Financial Statements as at 31.12.2016, "Ovidius" University Annals, Economic Sciences Series, XVII (2), pp. 588-592, Available: http://stec.univ-ovidius.ro/html/anale/ENG/ovidius-university-annals-economic-sciences-se ries-volume-xvii-issue-2l, [accessed at 05 Jan 2019].

Mock, T.J., Bedard, J., Coram, P.J., Davis, S.M., Espahbodi, R., and Warne R.C., 2013. The audit reporting model: current research synthesis and implications, Auditing: A Journal of Practice and Theory, 32 (1), pp. 323-351.

Robu, I.B., Grosu, M., Istrate, C., 2016. The effect of the Auditor's Rotation on the Accounting Quality in the Case of Romanian Listed Companies under the Transition to IFRS, Audit Financiar Journal, 1 (133), pp. 65-77.

\section{Bio-note}

Andreea Crucean, is a PhD student in the field of Accounting and Audit, member at East European Center for Research in Economics and Business from the West University of Timisoara. As a young researcher, Andreea focused on the quality and integrity of the services that an auditor provides for the enterprises, researching this area in her papers. 